九州大学学術情報リポジトリ

Kyushu University Institutional Repository

\title{
Avai labilities of Phosphorus Compounds as Dietary Phosphorus Sources for Red Sea Bream
}

Sakamoto, Syuichi

Fishery Research Laboratory, Kyushu University

Yone, Yasuo

Fishery Research Laboratory, Kyushu University

https://doi.org/10.5109/23689

出版情報: 九州大学大学院農学研究院紀要. 23 (3/4), pp.177-184, 1979-03. Kyushu University バージョン：

権利関係 : 


\title{
Availabilities of Phosphorus Compounds as Dietary Phosphorus Sources for Red Sea Bream*
}

\author{
Syuichi Sakamoto and Yasuo Yone \\ Fishery Research Laboratory, Kyushu University 46-12, \\ Tsuyazaki, Fukuoka 811-33
}

(Received December 9, 1978)

\begin{abstract}
Three experiments were conducted to compare the availabilities of eight phosphorus compounds as a phosphorus sources in the diet for red sea bream, Chrysophrys major. Phosphorus contents of the test diets were adjusted to $680 \mathrm{mg}$ per $100 \mathrm{~g}$ of diet in each experiment. The fish were reared on the test diets at $25^{\circ} \mathrm{C}$ over a 77 day period (Exp. I), 62 day period (Exp. II), and an 88 day period (Exp. III). At the end of the feeding trial, ten fish from each group were selected for the chemical analyses of the blood serum, liver, and vertebrae. Sodium phosphates (mono-, di-, and tribasic), potassium phosphate monobasic, and calcium phosphate monobasic were more effective than calcium phosphates (di- and tribasic) to prevent the development of phosphorus deficiency symptoms. Calcium phytate was scarcely utilized as the dietary phosphorus source by red sea bream. Therefore, the water soluble phosphorus compounds, from which inorganic phosphorus is easily released, should be employed as the dietary phosphorus source for red sea bream.
\end{abstract}

\section{INTRODUCTION}

When sodium phosphate monobasic was used as the dietary phosphorus source, red sea bream fed the diet containing phosphorus at less than $680 \mathrm{mg}$ per $100 \mathrm{~g}$ level exhibited various phosphorus deficiency symptoms (Sakamoto and Yone, 1973; Sakamoto and Yone, 1978). On the other hand, in the diet of rainbow trout, Salmo gairdneri, (Ogino and Takeda, 1974; Takeda and Ogino, 1975) and carp, Cyprinus carpio, (Takeda and Ogino, 1975; Shitanda and Ukita, 1979), it has been reported that the physicochemical form of phosphorus compounds affects phosphorus absorption. Therefore, in this study, three experiments were conducted to compare the availabilities of eight phosphorus compounds in the diet for red sea bream.

\section{MATERIALS AND METHODS}

The dietary phosphorus sources used were: sodium phosphate monobasic, potassium phosphate monobasic, and calcium phosphate monobasic in experi-

\footnotetext{
* Contribution from Fish. Res. Lab., Kyushu Univ., No. 135. This work was orally presented to the Annual Meeting of Japan. Soc. Sci. Fish., at Tokyo in April, 1978.
} 
ment I; sodium phosphate mono-, di-, and tribasic in experiment II; and calcium phosphate mono-, di-, and tribasic and calcium phytate (phytin) in experiment III. These phosphorus compounds were supplemented to test diets

Table 1. Composition of test diet.

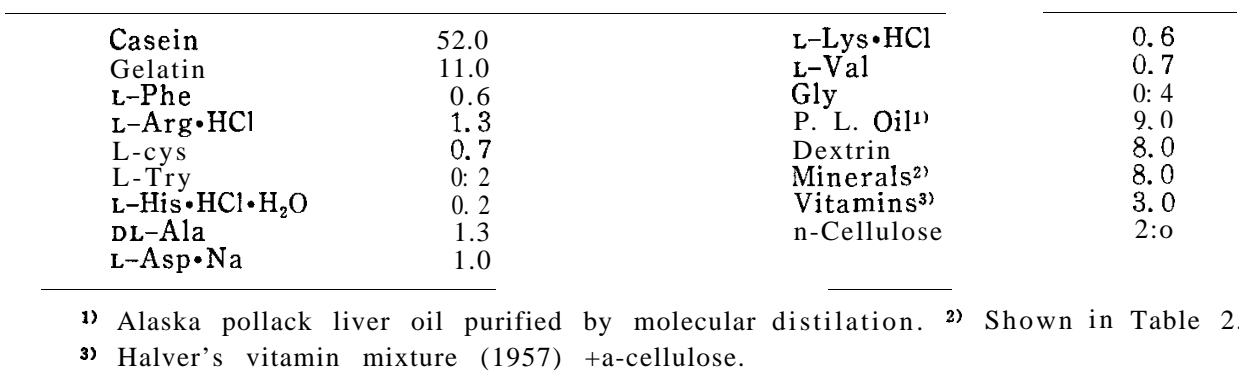

Table 2. Composition of mineral mixtures.

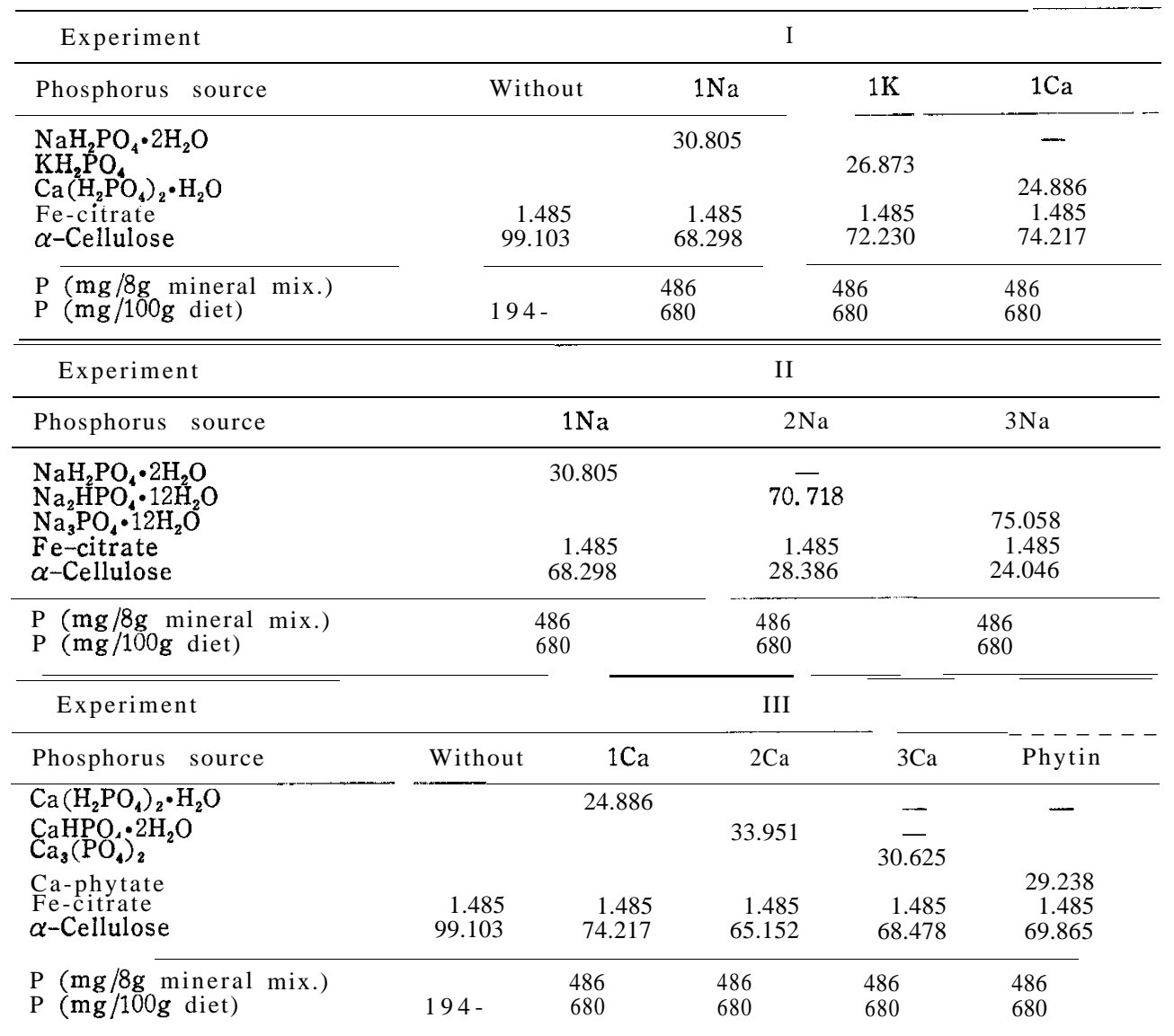


at a $680 \mathrm{mg} \mathrm{P}$ per $100 \mathrm{~g}$ diet level. The composition of test diets and mineral mixtures are listed in Table 1 and Table 2, respectively. The fish were reared on the test diet at $25^{\circ} \mathrm{C}$ over a 77 day period (Exp. I), 66 day period (Exp. II), and an 88 day period (Exp. III). The methods of fish selection, grouping, care, preparation of diets, and feeding were the same as those reported previously (Yone et al., 1974). At the end of the feeding trial, ten fish from each group were selected. A blood sample was taken from each fish by a cardiac puncture for the chemical analyses of serum. Calcium and inorganic phosphorus content of the blood serum was quantified by orthocresolphthalein complexone (Conerty and Briggs, 1966) and molybdenum blue method (Tausky and Shorr, 1953), respectively. The blood serum levels of glucose, total protein, total bilirubin, total cholesterol, and urea-N (BUN), and the activities of glutamic oxaloacetic transaminase (GOT), glutamic pyruvic transaminase (GPT), lactic dehydrogenase (LDH), leucine aminopeptidase (LAP), and alkaline phosphatase (ALP) in the blood serum were determined with Rapid Blood Analyzer 3010 and Unikit (Chugai Pharmaceutical Co.). After the blood sampling, the fork length and the weight of entire body and liver were measured. From these values, the condition factor and the percentage of liver to body weight (hepatosomatic index) were calculated. The analytical samples of the liver and vertebrae were taken from each fish in the same amount, and were mixed thoroughly in each group. Moisture contents of the liver and vertebrae were determined by a 24 hour drying in an electric oven at $105^{\circ} \mathrm{C}$. Lipid content of the liver was quantified by extraction with ethyl ether for 16 hours, and lipid in the vertebrae was extracted with methyl alcohol for 24 hours followed by a 16 hour extraction with ethyl ether. Glycogen content of the liver was determined by the method of Carroll et al. (1956). The phosphorus content of liver was analysed by molybdenum blue method (Tausky and Shorr, 1953) after wet ashing with nitric acid and hydrogen peroxide. The calcium and phosphorus content of vertebrae were quantified by orthocresolphthalein complexone (Conerty and Briggs. 1966) and molybdenum blue method (Tausky and Shorr, 1953), respectively, after dry ashing with an electric furnace at $450^{\circ} \mathrm{C}$ for 48 hours.

\section{RESULTS AND DISCUSSION}

\section{Experiment I}

No significant differences were recognized among the groups fed the diets with sodium-, potassium-, and calcium phosphate monobasic in the following determinations: the growth rate, feed efficiency, condition factor, and hepatosomatic index (Table 3) ; the blood serum levels of calcium, inorganic phosphorus, glucose, total protein, total bilirubin, total cholesterol, and BUN (Table 4); the activities of GOT, GPT, LDH, LAP, and ALP in the blood serum (Table 4) ; the moisture, lipid, glycogen, and phosphorus content of liver (Table 5) ; and the lipid, ash, calcium, and phosphorus content of vertebrae (Table 5). From these findings, it appears that sodium phosphate monobasic, 
Table 3. Effect of dietary phosphorus compounds on the growth rate, feed efficiency, condition factor, and hepatosomatic index of red sea bream in experiment $\mathrm{I}$.

\begin{tabular}{|c|c|c|c|c|}
\hline Phosphorus source & Without & $1 \mathrm{Na}$ & $1 \mathrm{~K}$ & $1 \mathrm{Ca}$ \\
\hline \multicolumn{5}{|l|}{ No. of fish } \\
\hline Sat start & 20 & 20 & 20 & 20 \\
\hline lafter 77 days & 19 & 20 & 20 & 20 \\
\hline $\mathrm{A}\left\{\begin{array}{l}\text { erage body weight } \\
\text { at after start } 77 \text { days }\end{array}\right.$ & $49.6 \pm 94.1113 .84 .5$ & $109.3 \pm 13.649 .8 \pm 5.1$ & $107.449 .6 \pm \pm 14.04 .8$ & $110.2 \pm 16.149 .5 \pm 5.2$ \\
\hline “t” test $(5 \%)$ & 54 & & $\mathrm{NS}^{22}$ & NS \\
\hline Feed efficiency (o/ $)$ & $2.35 \pm 0.13$ & 71 & 71 & 72 \\
\hline $\begin{array}{l}\text { Condition factor }{ }^{3)} \\
\text { “ } t \text { " test }(5 \%)\end{array}$ & NS & $2.44 \pm 0.05$ & $\underset{\mathrm{NS}}{2.42 \pm 0.07}$ & $\begin{array}{l}2.46 \pm 0.10 \\
\mathrm{NS}\end{array}$ \\
\hline $\begin{array}{l}\text { Hepatosomatic index }(\%)^{4)} \\
\text { "t" test }(5 \%)\end{array}$ & $\begin{array}{c}1.68 \pm 0.35 \\
\mathrm{NS}\end{array}$ & $1.72 \pm 0.39$ & $\begin{array}{c}1.63 \pm 0.33 \\
\mathrm{NS}\end{array}$ & $\underset{\mathrm{NS}}{1.54 \pm 0.32}$ \\
\hline
\end{tabular}

1) Significant. 2) Non-significant. 3) Body weight (g) $x 100 /\{\text { Folk length (cm) }]^{3}$.

4) Liver weight $(\mathrm{g}) \times 100 /$ Body weight $(\mathrm{g})$.

Table 4. Effect of dietary phosphorus compounds on the levels of chemical components and the activities of enzymes in blood serum of red sea bream in experiment $\mathrm{I}$.

\begin{tabular}{|c|c|c|c|c|}
\hline Phosphorus source & Without & $1 \mathrm{Na}$ & $1 \mathrm{~K}$ & $1 \mathrm{Ca}$ \\
\hline $\begin{array}{l}\text { Ca }(\mathrm{mg} / \mathrm{d} l) \\
\text { Inorganic } \mathrm{P}(\mathrm{mg} / \mathrm{d} l) \\
\text { Ca } / \mathrm{P} \text { ratio } \\
\text { Glucose }(\mathrm{mg} / \mathrm{d} l) \\
\text { Total protein }(\mathrm{g} / \mathrm{d} l) \\
\text { Total bilirubin }(\mathrm{mg} / \mathrm{d} l) \\
\text { Total cholesterol }(\mathrm{mg} / \mathrm{d} l) \\
\text { BUN (mg/d })\end{array}$ & $\begin{array}{r}15.0 \\
6.1 \\
2.5 \\
79 \\
4.1 \\
1.2 \\
255 \\
12.5\end{array}$ & $\begin{array}{r}12.9 \\
8.9 \\
1.4 \\
65 \\
4.0 \\
0.7 \\
236 \\
10.5\end{array}$ & $\begin{array}{r}12.9 \\
8.9 \\
1.4 \\
65 \\
4.0 \\
0.9 \\
231 \\
11.7\end{array}$ & $\begin{array}{r}12.7 \\
8.7 \\
1.5 \\
67 \\
4.0 \\
0.7 \\
210 \\
13.5\end{array}$ \\
\hline $\begin{array}{l}\text { GOT (K. U.) }{ }^{1)} \\
\text { GPT }(\text { K.U.) } \\
\text { GOT /GPT ratio } \\
\text { LDH (W. U.) } \\
\text { LAP (G.-R. U.) }{ }^{3)} \\
\text { ALP (K.-A. U.) }\end{array}$ & $\begin{array}{c}122 \\
65 \\
1.9 \\
1635 \\
630 \\
5.9\end{array}$ & $\begin{array}{c}154 \\
62 \\
-2.5 \\
1530 \\
765 \\
3.5\end{array}$ & $\begin{array}{c}148 \\
67 \\
2.2 \\
1527 \\
795 \\
3.4\end{array}$ & $\begin{array}{c}187 \\
95 \\
2.0 \\
1515 \\
895 \\
3.4\end{array}$ \\
\hline
\end{tabular}

1) Karmen Unit. 2) Wroblewski Unit. 3) Goldberg-Ruteinburg Unit.

4) King-Armstrong Unit.

potassium phosphate monobasic, and calcium phosphate monobasic are equally available as a dietary phosphorus source for red sea bream.

\section{Experiment II}

In the group fed the diet supplemented with sodium phosphate dibasic, the feed efficiency, condition factor, and hepatosomatic index were lower than those of sodium phosphate monobasic and tribasic diet groups (Table 6), whereas the glucose content and activities of GOT, GPT, and LDH in the blood serum were higher (Table 7). However, the dibasic group was similar to the monobasic and tribasic groups in the following determinations: the blood se- 
Table 5. Effect of dietary phosphorus compounds on the chemical components in liver and vertebrae of red sea bream in experiment $I$.

\begin{tabular}{|c|c|c|c|c|}
\hline Phosphorus source & Without & $1 \mathrm{Na}$ & $1 \mathrm{~K}$ & $1 \mathrm{Ca}$ \\
\hline \multicolumn{5}{|l|}{ Liver } \\
\hline Moisture (\%) & 64.5 & 67.4 & 67.3 & 68.2 \\
\hline Lipid (\% db) & 43. 1 & 30.3 & 31.3 & 34.6 \\
\hline Glycogen $(\% \mathrm{db})$ & 9.1 & 16.0 & 14.7 & 12.6 \\
\hline $\mathrm{P}(\mathrm{mg} / 100 \mathrm{~g} \mathrm{db})$ & 589 & 651 & 639 & 640 \\
\hline \multicolumn{5}{|l|}{ Vertebrae } \\
\hline Lipid ( $\%$ db) & 24.4 & 23.3 & 22.1 & 21.8 \\
\hline Ash $(\%, d b)$ & 47.5 & 50.7 & 50.4 & 50.1 \\
\hline $\mathrm{Ca}(\mathrm{mg} / \mathrm{g}$ ash $)$ & 347 & 354 & 353 & 352 \\
\hline $\mathrm{P}(\mathrm{mg} / \mathrm{g}$ ash $)$ & 172 & 177 & 176 & 175 \\
\hline $\mathrm{Ca}_{\mathrm{a}} / \mathrm{P}$ ratio & 2. 0 & 2. 0 & 2.0 & 2.0 \\
\hline
\end{tabular}

1) $\%$ on dry weight basis.

Table 6. Effect of dietary phosphorus compounds on the growth rate, feed efficiency, condition factor, and hepatosomatic index of red sea bream in experiment II.

\begin{tabular}{|c|c|c|c|}
\hline Phosphorus source & $1 \mathrm{Na}$ & $2 \mathrm{Na}$ & $3 \mathrm{Na}$ \\
\hline $\begin{array}{l}\text { No. of fish } \\
\text { at start } \\
\text { Iafter } 62 \text { days }\end{array}$ & $\begin{array}{l}20 \\
20\end{array}$ & $\begin{array}{l}20 \\
19\end{array}$ & $\begin{array}{l}20 \\
20\end{array}$ \\
\hline $\begin{array}{l}\text { Average body weight }(\mathrm{g}) \\
\quad\left\{\begin{array}{l}\text { at start } \\
\text { after } 62 \text { days }\end{array}\right. \\
\text { "t" test }(5 \%)\end{array}$ & $\begin{array}{l}10.3 \pm 1.2 \\
33.4 \pm 7.7\end{array}$ & $\begin{array}{c}10.3 \pm 1.3 \\
31.3 \pm 6.2 \\
\text { NS }\end{array}$ & $\begin{array}{c}10.3 \pm 1.3 \\
33.9 \pm 6.2 \\
\mathrm{NS}\end{array}$ \\
\hline Feed efficiency $(\%)$ & 93 & a5 & 86 \\
\hline $\begin{aligned} \text { Condition factor } \\
\text { “t” test } \\
(5 \%)\end{aligned}$ & $2.28 \pm 0.11$ & $\underset{\mathrm{NS}}{2.19 \pm 0.10}$ & $2.27 \pm 0.10$ \\
\hline $\begin{array}{l}\text { Hepatosomatic index }(\%) \\
\text { "t" test }(5 \%)\end{array}$ & $2.28 \pm 0.52$ & $\underset{\mathrm{NS}}{1.84 \pm 0.51}$ & $2.55 \pm 0.44$ \\
\hline
\end{tabular}

Table 7. Effect of dietary phosphorus compounds on the levels of chemical components and the activities of enzymes in blood serum of red sea bream in experiment II.

\begin{tabular}{|c|c|c|c|}
\hline Phosphorus source & $1 \mathrm{Na}$ & $2 \mathrm{Na}$ & $3 \mathrm{Na}$ \\
\hline $\begin{array}{l}\text { Ca }(\mathrm{mg} / \mathrm{d} l) \\
\text { Inorganic } \mathrm{P}(\mathrm{mg} / \mathrm{d} l) \\
\text { Ca/P ratio } \\
\text { Glucose }(\mathrm{mg} / \mathrm{d} l) \\
\text { Total protein }(\mathrm{g} / \mathrm{d} l) \\
\text { Total bilirubin }(\mathrm{mg} / \mathrm{d} l) \\
\text { Total cholesterol }(\mathrm{mg} / \mathrm{d} l) \\
\text { BUN (mg } / \mathrm{d} l)\end{array}$ & $\begin{array}{r}11.0 \\
7.7 \\
1.4 \\
72 \\
3.5 \\
2300.4 \\
9 . a\end{array}$ & $\begin{array}{r}11.2 \\
7.8 \\
1.4 \\
93.6 \\
0.5 \\
221 \\
11.1\end{array}$ & $\begin{array}{c}11.3 \\
7.0 \\
1.6 \\
75 \\
3.9 \\
0.4 \\
261 \\
10.9\end{array}$ \\
\hline $\begin{array}{l}\text { GOT (K. U.) } \\
\text { GBT /GPTratio } \\
\text { LDH (W. U.) } \\
\text { LAP (G.-K. U.) } \\
\text { ALP (K.-A. U.) }\end{array}$ & $\begin{array}{c}5514 \\
3.9 \\
1030 \\
721 \\
4.6\end{array}$ & $\begin{array}{c}\text { la7 } 62 \\
3.0 \\
>2630^{\circ} \\
737 \\
5.1\end{array}$ & $\begin{array}{c}5719 \\
3.0 \\
1590 \\
711 \\
4.6\end{array}$ \\
\hline
\end{tabular}


Table 8. Effect of dietary phosphorus compounds on the chemical components in liver and vertebrae of red sea bream in experiment II.

\begin{tabular}{|c|c|c|c|}
\hline Phosphorus source & $1 \mathrm{Na}$ & $2 \mathrm{Na}$ & $3 \mathrm{Na}$ \\
\hline $\begin{array}{l}\text { Liver } \\
\text { Moisture }(\%) \\
\text { Lipid (\% db) } \\
\text { Glycogen }(\% \mathrm{db})\end{array}$ & $\begin{array}{l}65.3 \\
33.4 \\
17.3\end{array}$ & $\begin{array}{l}64.5 \\
36.7 \\
17.4\end{array}$ & $\begin{array}{l}64.2 \\
35.0 \\
19.3\end{array}$ \\
\hline $\begin{array}{l}\text { Vertebrae } \\
\text { Lipid }(\% \mathrm{db}) \\
\text { Ash }(\% / \mathrm{db}) \\
\text { Ca (mg/g ash }) \\
\text { P (mg/g ash) } \\
\text { Ca/P ratio }\end{array}$ & $\begin{array}{c}22.6 \\
51.2 \\
354 \\
188 \\
1.9\end{array}$ & $\begin{array}{c}22.1 \\
51.3 \\
355 \\
188 \\
1.9\end{array}$ & $\begin{array}{c}22.8 \\
51.3 \\
354 \\
187 \\
1.9\end{array}$ \\
\hline
\end{tabular}

rum levels of calcium and inorganic phosphorus; the ALP activity in the blood serum; the moisture, lipid, and glycogen content of the liver; and the lipid and ash content of the vertebrae (Tables 7 and 8). Therefore, it can be considered that the fish fed the diet supplemented with sodium phosphate dibasic were not in the phosphorus deficiency state. The test diet supplemented with sodium phosphate tribasic could not be cut into cubes with a suitable size owing to its adhesiveness, so this diet was crushed in the sea water and given to fish. A part of this crushed diet was not consumed. Therefore, the feed efficiency of tribasic group was inferior to that of monobasic group, but other values were similar (Table 6). From these findings, it can be presumed that these three sodium phosphates (mono-, di-, and tribasic) are equally available as a dietary phosphorus source for red sea bream.

\section{Experiment III}

As shown in Tables 9, 10, and 11, the phytin group exhibited lower values than the calcium phosphate monobasic group in the following parameters: the growth rate and feed efficiency; the blood serum level of inorganic phosphorus ; the moisture, glycogen, and phosphorus content of liver; and the ash con-

Table 9. Effect of dietary phosphorus compounds on the growth rate, feed efficiency, condition factor, and hepatosomatic index of red sea bream in experiment III.

\begin{tabular}{|c|c|c|c|c|c|}
\hline Phosphorus source & Without & $1 \mathrm{Ca}$ & $2 \mathrm{Ca}$ & $3 \mathrm{Ca}$ & Phytin \\
\hline \multicolumn{6}{|l|}{ No. of fish } \\
\hline$\left\{\begin{array}{l}\text { at start } \\
\text { after } 88 \text { days }\end{array}\right.$ & $\begin{array}{l}15 \\
14\end{array}$ & $\begin{array}{l}15 \\
15\end{array}$ & $\begin{array}{l}15 \\
15\end{array}$ & $\begin{array}{l}15 \\
15\end{array}$ & $\begin{array}{l}15 \\
14\end{array}$ \\
\hline A\} $\left\{\begin{array}{l}\text { erage body weight } \\
\text { at after start } 88 \text { days }\end{array}\right.$ & $15 \% .4 \pm 19.882 .7 \pm 6.1$ & $172.1 \pm 21.882 .5 \pm 6.3$ & $170.1 \pm 23.482 .6 \pm 5.8$ & $169.3 \pm 35.082 .5 \pm 5.6$ & $157.4 \mathrm{tr} 31.7 \quad 82.6616 .2$ \\
\hline "t" test $(5 \%)$ & S & & NS & NS & NS \\
\hline Feed efficiency $(\mathscr{Q})$ & 57 & 70 & 70 & 72 & 62 \\
\hline $\begin{array}{l}\text { Condition factor } \\
\text { "t" test }(5 \%)\end{array}$ & $2.38+0.06$ & $2.45 \pm 0.08$ & $2.49+0.07$ & $2.56 \frac{+0.14}{\mathrm{~S}}$ & $2.44 \pm 0.15$ \\
\hline $\begin{array}{l}\text { Hepatosomatic index }(\%) \\
\text { "t" test }(5 \%)\end{array}$ & $\begin{array}{c}1.64 \mathrm{t} 0.69 \\
\mathrm{NS}\end{array}$ & $1.62 \pm 0.22$ & $\begin{array}{c}1.68 \mathrm{t} 0.32 \\
\mathrm{NS}\end{array}$ & $1.72+0.46$ & $\begin{array}{c}1.70 \mathrm{i} 0.22 \\
\mathrm{NS}\end{array}$ \\
\hline
\end{tabular}


Table 10. Effect of dietary phosphorus compounds on the Ievels of chemical components and the activities of enzymes in blood serum of red sea bream in experiment III.

\begin{tabular}{|c|c|c|c|c|c|}
\hline Phosphorus source & Without & $1 \mathrm{Ca}$ & $2 \mathrm{Ca}$ & $3 \mathrm{Ca}$ & Phytin \\
\hline $\mathrm{Ca}(\mathrm{mg} / \mathrm{d} l)$ & $\begin{array}{r}14.6 \\
5.8\end{array}$ & 13.9 & 14.3 & 15.3 & 15. 4 \\
\hline $\mathrm{Ca} / \mathrm{P}$, anatioP $(\mathrm{mg} / \mathrm{d} l)$ & 2.5 & 9.5 & 8.6 & 8.9 & $\begin{array}{l}0.4 \\
2.4\end{array}$ \\
\hline Glucose $(\mathrm{mg} / \mathrm{d} l)$ & 76 & 74.0 & 77 & 79 & $7 \overline{4}$ \\
\hline Total protein $(\mathrm{g} / \mathrm{d} l)$ & 4.2 & 0.9 & 4.3 & 4. a & 4.6 \\
\hline Total bilirubin (mg/dl) & 1.0 & 0.9 & 1.0 & 1.0 & 1.3 \\
\hline Total cholesterol $(\mathrm{mg} / \mathrm{d} l)$ & 240 & 189' & 191 & 229 & 236 \\
\hline $\mathrm{BUN}(\mathrm{mg} / \mathrm{d} l)$ & 14.6 & 9.9 & 10.3 & 11.9 & a. 7 \\
\hline GOT (K. U.) & 80 & 79 & 76 & 80 & 76 \\
\hline GPT (K. U.) & 42 & 37 & 36 & 40 & 37 \\
\hline GOT/GPT ratio & 1.9 & $\stackrel{2.1}{1140}$ & $\begin{aligned} 2 . & 1\end{aligned}$ & 2. 0 & $1380^{2.0}$ \\
\hline LAP (G.-R. U.) & 538 & 679 & 661 & $\begin{array}{r}1120 \\
646\end{array}$ & $\begin{array}{r}1000 \\
712\end{array}$ \\
\hline ALP (K. -A. Ü.) & 4.0 & 2. 6 & 3.3 & 3.6 & 4.2 \\
\hline
\end{tabular}

Table 11. Effect of dietary phosphorus compounds on the chemical components in liver and vertebrae of red sea bream in experiment III.

\begin{tabular}{lccccc}
\hline Phosphorus source & Without & $1 \mathrm{Ca}$ & $2 \mathrm{Ca}$ & $3 \mathrm{Ca}$ & Phytin \\
\hline Liver & & & & & \\
Moisture (\%) & 54.9 & 68.6 & 63.7 & 54.4 & 54.6 \\
Lipid (\% db) & 62.8 & 29.9 & 41.6 & 62.2 & 60.1 \\
Glycogen (\% db) & 5.1 & 14.4 & 10.4 & 6.1 & . 5 \\
P (mg/100g db) & 346 & 700 & $\mathbf{6 0 8}$ & $\mathbf{4 2 9}$ & 375 \\
Vertebrae & & & & 25.6 & 26.7 \\
Lipid (\% db) & 28.9 & 24.3 & 25.0 & 48.1 & 45.1 \\
Ash (\% db) & 43.4 & 50.5 & 49.0 & 351 & 355 \\
Ca (mg/g ash) & 364 & 354 & 354 & 171 & 171 \\
P (mg/g ash) & 170 & 172 & 172 & 2.1 & 2.1 \\
Ca/P ratio & 2.1 & 2.1 & 2.1 & &
\end{tabular}

tent of vertebrae. However, the $\mathrm{Ca} / \mathrm{P}$ ratio and $\mathrm{ALP}$ activity in the blood serum and the lipid contents of liver and vertebrae were higher. These values for the phytin group were similar to those of the group fed the diet without phosphorus supplementation. It appears that phosphorus in calcium phytate is scarcely utilized by red sea bream. In the above determinations, the calcium phosphate di- and tribasic groups showed different values from the monobasic group, but the growth rates and feed efficiencies were similar. From these findings, it is reasonable to presume that phosphorus in calcium phosphates (di- and tribasic) is considerably utilized, but its utilization rate, especially in tribasic form, is inferior to that in calcium phosphate monobasic.

In rainbow trout (Ogino and Takeda, 1974; Takeda and Ogino, 1975) and carp (Takeda and Ogino, 1975; Shitanda and Ukita, 1979), it was proven that the absorption rate of phosphorus from soluble phosphorus compounds were higher than that from insoluble compounds and phytin. In this study, soluble phosphorus compounds (sodium phosphate mono-, di-, and tribasic, potassium phosphate monobasic, and calcium phosphate monobasic) were more effective 
than insoluble compounds (calcium phosphate di- and tribasic) and phytin in preventing the development of phosphorus deficiency symptoms. Perhaps, the absorption rates of phosphorus from insoluble compounds are lower than those from soluble compounds in red sea bream also. The poor availability of phy. tin as the dietary phosphorus source may be due to the inability of inorganic phosphorus to be released. Therefore, the water soluble phosphorus compounds, from which inorganic phosphorus is easily released, should be employed as the dietary phosphorus source for red sea bream.

\section{REFERENCES}

Carroll, N. V., R. W. Longley, and J. H. Roe 1956 The determination of glycogen in liver and muscle by use of anthrone reagent. J. Biol.Chem.,220(2):583-593

Conerty, H. V. and A. R. Briggs 1966 Determination of serum calcium by means of orthocresolphthalein complexone. Am. J. Clin. Path.. 45(3) : 290-296

Ogino. C. and H. Takeda 1974 Availabilities of various phosphorous compounds as dietary phosphorus sources for rainbow trout. The abstract of oral presentation on annual meeting of Japan. Soc. Sci. Fish. at Kyoto in November, p. 11 (in Japanese)

Sakamoto, S. and Y. Yone 1973 Effect of dietary calcium/phosphorus ratio upon growth, feed efficiency and blood serum $\mathrm{Ca}$ and $\mathrm{P}$ level in red sea bream. Bull. Japan. Soc. Sci. Fish., 39(4): 343-348

Sakamoto, S. and Y. Yone 1978 Effect of dietary phosphorus level on chemical composition of red sea bream. Bull. Japan. Soc. Sci. Fish., 44(3): 227-229

Shitanda, K. and M. Ukita 1979 Effect of various phosphate addition in compounded feed on growth, feed efficiency, and blood serum levels of inorganic phosphorus and calcium of carp and sparing effect for white fish meal. The aquiculture, 21: in press (in Japanese)

Takeda, H. and C. Ogino 1975 Phosphorus absorption of carp and rainbow trout from dietary phosphorus compounds. The abstract of oral presentation on annual meeting of Japan. Soc. Sci. Fish. at Nagasaki in 0 ctober, p. 96 (in Japanese)

Tausky. H. H. and E. Shorr 1953 A microcolorimetric method for the determination of inorganic phosphorus. J. Biol. Chem., 202(2): 675-685

Yone, Y., S. Sakamoto, and M. Furuichi 1974 Studies on nutrition of red sea bream-IX. The basal diet for nutrition studies. Rep. Fish. Res. Lab., Kyushu Univ., No. 2: 13-24 